\title{
KESIAPAN DESA TANJUNG TERDANA KABUPATEN BENGKULU TENGAH DALAM PENGELOLAAN ALOKASI DANA DESA (ADD)
}

\author{
Oleh:
}

\author{
NURSANTY, YORRY HARDAYANI, LOESIDA ROELIANA \\ Dosen Program Studi Administrasi Negara FISIP Universitas Bengkulu
}

\begin{abstract}
This study aimed to see the readiness of Tanjung Terdana village in funds management on the Village Fund Allocation. The readiness could be seen from four aspects, namely: 1) device regulations/guidelines for the implementation readiness, 2) Human Resources readiness, 3) governance readiness, 4) Participation of the community. The results showed that although at first Tanjung Terdana village did not understand about the concept of financial management in particular the Village Fund Allocation which nominal was much greater than before, but they had the commitment and progress to develop the village by utilizing the Village Fund Allocation. So even though the implementing regulations at the local level was slow set so that governance couldn't be run in accordance with a predetermined schedule, but head of the village and village officials consulted to a number of parties. Their willingness to learn, correct errors, effort, and along with community participation then slowly increased their readiness on managed the Village Fund Allocation.
\end{abstract}

Keywords: Village Readiness, Village Fund Allocation, Tanjung Terdana

\section{PENDAHULUAN}

Disahkannya Undang-Undang Nomor 6 Tahun 2014 tentang Desa pada tanggal 15 Januari 2014 membuat pengaturan tentang desa mengalami perubahan secara signifikan. Dari sisi regulasi, desa tidak lagi menjadi bagian dari Undang-Undang Nomor 32 tahun 2004 tentang Pemerintahan Daerah. Desadesa di Indonesia akan mengalami reposisi dan pendekatan baru dalam pelaksanaan pembangunan dan tata kelola pemerintahannya. Pada hakikatnya Undang-Undang tentang Desa memiliki visi yang memberikan kewenangan luas kepada desa dibidang penyelenggaraan pemerintahan desa, pelaksanaan pembangunan desa, pembinaan kemasyarakatan desa, dan pemberdayaan masyarakat desa berdasarkan prakarsa masyarakat, hak asal usul, dan adat istiadat desa.

Undang-Undang tentang desa juga memberi jaminan yang lebih pasti bahwa setiap desa akan menerima dana dari pemerintah melalui anggaran negara dan daerah yang jumlahnya berlipat, jauh di atas jumlah yang selama ini tersedia dalam anggaran desa. Kebijakan ini memiliki konsekuensi terhadap proses pengelolaannya yang seharusnya dilaksanakan secara profesional, efektif dan efisien, serta akuntabel yang didasarkan pada prinsip-prinsip manajemen publik yang baik agar terhindarkan dari resiko terjadinya penyimpangan, penyelewengan dan korupsi. Pemerintah dan DPR memiliki komitmen yang kuat terkait kebijakan ini, yang dibuktikan dengan telah disetujuinya anggaran dana desa sejumlah Rp.20,7 triliun dalam Anggaran Pendapatan dan Belanja Negara Perubahan (APBNP) 2015 yang akan disalurkan ke 74.093 desa di seluruh Indonesia. Pemerintah menargetkan agar anggaran tersebut dapat segera tersalurkan ke seluruh desa (Laporan hasil kajian pengelolaan keuangan desa: Dana Desa dan Alokasi Dana Desa (ADD) yang disusun oleh Komisi Pemberantasan Korupsi (KPK) 
www.kpk.go.id diakses tanggal 2 Juli 2015).

Lebih lanjut, dalam laporan tersebut juga menyebutkan bahwa selain dana desa, desa juga memperoleh dana yang dikenal dengan ADD yang berasal dari bagian dana perimbangan keuangan pusat dan daerah yang diterima oleh kabupaten/kota. Potensi jumlah ADD yang mengalir ke desa diperkirakan sekitar Rp.40 triliun sampai dengan Rp.50 triliun di tahun 2015 ini. Tergambar bahwa saat ini desa akan mengelola sekurangkurangnya dana seperempat miliar per tahunnya. Besaran dana tiap desa akan berbeda-beda, sesuai dengan jumlah penduduk, angka kemiskinan, luas wilayah, dan tingkat kesulitan geografisnya.

Anggaran sebesar itu untuk setiap desa memunculkan kekhawatiran tersendiri akan efektivitas dan transparansi penggunaannya. Jumlah sebesar itu tidak tepat sasaran bahkan akan sia-sia tanpa kesiapan yang optimal dari tingkat pusat hingga desa sebagai pelaksananya.

Di provinsi Bengkulu terdapat 1.341 desa yang tersebar di sepuluh Kabupaten/Kota, diantaranya adalah 112 desa di Kabupaten Bengkulu Tengah dan 182 desa di Kabupaten Seluma. Desa Tanjung Terdana merupakan salah satu desa di Kabupaten Bengkulu Tengah yang delapan puluh persen penduduknya adalah suku asli Bengkulu, yaitu suku Lembak. Jumlah penduduknya adalah 935 jiwa dengan 252 Kepala Keluarga (KK). Sebagian besar mata pencaharian masyarakat desa Tanjung Terdana adalah sebagai petani. Hal ini menjadi salah satu penyebab rendahnya tingkat partisipasi masyarakat dalam kegiatan-kegiatan pembangunan desa. Waktu yang lebih banyak dihabiskan di sawah menyebabkan kurang optimalnya kegiatan jika dilakukan di siang hari karena jarangnya masyarakat yang ikut serta berpartisipasi dalam kegiatan-kegiatan pembangunan desa, sedangkan jika dilakukan di malam hari masyarakat sudah lelah karena sudah seharian bekerja. (Aminudin, dkk. 2014)

Kondisi tersebut di atas juga menjadi salah satu penyebab kurangnya Sumber Daya Manusia (SDM) dalam struktur organisasi pemerintahan desa. Perangkat desa yang ada tidak melaksanakan tugas sebagaimana mestinya dengan maksimal dikarenakan faktor kesibukan kesehariannya. Sehingga yang paling berperan dalam penyelenggaraan pemerintahan desa khususnya dalam pengelolaan keuangan desa adalah Kepala Desa, Sekretaris Desa, dan Bendahara Desa. Lantas apakah desa Tanjung Terdana sudah siap untuk mengelola keuangan desa yang sudah berkali lipat jumlahnya tersebut.

Rumusan masalah dalam penelitian ini adalah keberhasilan suatu kebijakan dipengaruhi oleh beberapa faktor, salah satunya adalah kesiapan perangkat pelaksanaannya. Kebijakan ADD akan mencapai tujuannya jika diiringi dengan kesiapan yang optimal, diantaranya adalah: kesiapan perangkat peraturan/pedoman pelaksanaan, kesiapan SDM pelaksana, kesiapan dalam tata laksana, dan adanya partisipasi masyarakat dan lembaga kemasyarakatan desa.

\section{METODE PENELITIAN}

Penelitian ini adalah penelitian kualitatif dengan menggunakan tehnik pengumpulan data dengan cara observasi, wawancara, Fokus Group Discussion (FGD), dan telaah dokumen. Data dianalisis dengan tehnik analisis interaktif berdasarkan teorinya Miles dan Huberman (dalam Sutopo, 2002:91-93), dimana analisisnya melalui tiga tahapan yaitu pengklasifikasian data, penyajian data, penerikan kesimpulan.

\section{HASIL DAN PEMBAHASAN Kesiapan Perangkat Peraturan/ Pedoman Pelaksanaan}

Kesiapan perangkat peraturan atau pedoman pelaksanaan pengelolaan ADD dilihat dari ketersediaan pedoman 
pelaksanaan dalam bentuk kebijakan petunjuk pelaksanaan dan petunjuk teknis pengelolaan keuangan desa, dimulai dari perencanaan, pelaksanaan, hingga pertanggung jawabannya penggunaannya. Peraturan tersebut adalah peraturan dari pemerintah pusat dan atau pemerintah daerah yang diketahui dan digunakan oleh perangkat desa dalam pengelolaan dana ADD.

Sebagaimana diketahui bahwa dalam pengelolaan ADD mempunyai serangkaian proses ataupun persyaratan yang harus dipenuhi. Rangkaian proses tersebut dimulai dari penyusunan rencana pembangunan dalam Rencana Pembangunan Jangka Menengah Desa (RPJMDes), Rencana Kerja Pemerintah Desa (RKPDes), dan sumber dan pembiayaan program pembangunan dalam Anggaran Pendapatan dan Belanja Desa (APBDes). Ketiga dokumen tersebut menjadi rangkaian yng harus dimiliki atau disusun dalam rangka pengelolaan keuangan desa. Dalam penyusunannya harus mengacu pada peraturan perundangan yang telah ditetapkan baik oleh pemerintah pusat maupun pemerintah daerah.

Pemerintah desa Tanjung Terdana telah mengetahui paraturan perundangan yang menjadi acuan dalam pengelolaan ADD, dimulai dari peraturan yang mengatur tentang perencanaan pembangunan hingga peraturan tentang keuangan desa. Peraturan perundangan yang dijadikan acuan oleh pemerintah desa Tanjung Terdana sebagaimana dijelaskan di atas adalah:

- Undang-Undang Nomor 6 Tahun 2014 Tentang Desa

- Undang-Undang Nomor 33 Tahun 2004 Tentang Perimbangan Keuangan Antara Pemerintah Pusat dan Daerah

- Peraturan Pemerintah Nomor 43 Tahun 2014 Tentang Peraturan Pelaksanaan Undang-Undang Nomor 6 Tahun 2014
- Peraturan Pemerintah Nomor 72 Tahun 2005 tentang Desa

- Peraturan Pemerintah Nomor 58 Tahun 2005 Tentang Pengelolaan Keuangan Daerah

- Peraturan Menteri Dalam Negeri Nomor 29 Tahun 2006 Tentang Pedoman Pembentukan dan Mekanisme Penyusunan Peraturan Desa.

- Peraturan Menteri Dalam Negeri Nomor 5 Tahun 2007 Tentang Pedoman Penataan Lembaga Kemasyarakatan

- Peraturan Menteri Dalam Negeri Nomor 66 Tahun 2007 Tentang Perencanaan Pembangunan Desa.

- Peraturan Menteri Dalam Negeri Nomor 36 Tahun 2007 Tentang Pengelolaan Keuangan Desa

- Peraturan Menteri Dalam Negeri Nomor 113 Tahun 2014 Tentang Pengelolaan Keuangan Desa

- Surat Menteri Dalam Negeri Nomor 414.2/1408/PMD Tanggal 31 Maret 2010 Tentang Petunjuk Teknis Perencanaan Pembangunan Desa.

- Peraturan Daerah Kabupaten Bengkulu Utara Nomor 5 Tahun 2007 Tentang Pemerintahan Desa

- Peraturan Daerah Kabupaten Bengkulu Utara Nomor 6 Tahun 2007 Tentang Keuangan Desa.

- Peraturan Daerah Kabupaten Bengkulu Tengah Nomor 06 Tahun 2011 Tentang Pemerintahan Desa dan Badan Permusyawaratan Desa.

- Peraturan Daerah Kabupaten Bengkulu Tengah Nomor 25 Tahun 2014 Tentang Penjabaran Anggaran Pendapatan dan Belanja Daerah Kabupaten Bengkulu Tengah Tahun Anggaran 2015.

- Peraturan Bupati Bengkulu Tengah Nomor 07 Tahun 2015 Tentang Tata Cara Pengalokasian dan Penyaluran Dana Desa. 
Kepala Desa beserta perangkatnya memiliki dan mempelajari peraturan perundangan tersebut di atas dibarengi dengan konsultasi pada pihak-pihak tertentu saat mengalami kesulitan dalam mengartikan isi dari peraturan perundangan tersebut. Hardcopy dari peraturan perundangan tersebut disatukan dalam satu odner dan selalu dibaca kembali saat dibutuhkan.

Peraturan perundangan tersebut merupakan panduan dalam pengelolaan keuangan desa secara keseluruhan, mulai dari penyusunan rencana pembangunan, pelaksanaan, dan pertanggungjawabannya. Tetapi jika dilihat dari isi peraturan perundangan tersebut di atas, belum ada peraturan yang secara khusus mengatur tentang pengelolaan ADD melainkan pengelolaan Dana Desa (DD) dan keuangan desa secara keseluruhan. Peraturan perundangan tersebut di atas meliputi aturan-aturan tentang hak dan kewenangan desa sebagai konsekuensi dari Undang-Undang Nomor 6 Tahun 2014 tentang desa, yang kemudian diikuti dengan peraturan perundangan lainnya seperti Peraturan Pemerintah, Peraturan Menteri, sampai Peraturan Daerah. Dalam daftar peraturan perundangan di atas juga sudah terdapat peraturan perundangan yang berisi tentang aturan-aturan dalam pengelolaan keuangan desa, aturan tentang pengelolaan DD secara khusus juga sudah ada, tetapi aturan yang secara khusus mengatur tentang pengelolaan ADD belum dipunyai oleh Kepala Desa Tanjung Terdana dan Perangkatnya. Selain itu, beberapa peraturan yang digunakan merupakan peraturan dari Pemerintah Daerah Kabupaten Bengkulu Utara, yang merupakan kabupaten induk dari pemekaran Kabupaten Bengkulu Tengah. Hal ini mengakibatkan terganggunya jadwal pelaksanaan agenda lainnya karena pembuatan peraturan daerah memerlukan waktu ditambah lagi waktu untuk memahami isi dari peraturan tersebut. Sebagai contoh adalah digunakannya Perda Kabupaten Bengkulu Utara tentang
Keuangan Desa dalam penyusunan APBDes, dan ditengah proses penyusunan APBDes tersebut Perda Kabupaten Bengkulu Tengah tentang Keuangan Desa ditetapkan, sehingga hal ini mempengaruhi proses penyusunan APBDes. Selain terkait dengan waktu penyelesaiannya yang menjadi terhambat juga dari muatan APBDes itu sendiri yang harus disesuaikan dengan Perda yang baru tersebut. Belum lagi diperlukannya waktu untuk memahami isi dari Perda tersebut.

Berdasarkan

peraturan perundangan tersebut di atas, pemerintah desa Tanjung Terdana telah membuat beberapa Peraturan Desa (Perdes) yang berhubungan dengan pengelolaan keuangan desa. Perdes yang telah disusun adalah Perdes Nomor 1 Tahun 2015 tentang RPJMDes, Perdes Nomor 2 Tahun 2015 tentang APBDes Tahun Anggaran 2015. Dari kedua Perdes tersebut kemudian dijadikan dasar dalam penyusunan RKPDes Desa Tanjung Terdana tahun 2015. Ketiga dokumen tersebut menjadi syarat dalam pengusulan dan pencairan dana pembangunan desa termasuk dana ADD tahun bersangkutan.

Pengelolaan keuangan desa di Desa Tanjung Terdana lebih terfokus pada keuangan desa yang bersumber dari DD daripada ADD. Sehingga peraturan perundangan yang dipelajari adalah peraturan yang berhubungan dengan pengelolaan DD. Sedangkan pemahaman tentang penggunaan ADD hanya dipahami secara umum bahwa peruntukannya adalah untuk operasional pemerintahan desa. Sebagaimana diketahui bahwa DD bersumber dari APBN dan peruntukannya bertujuan untuk peningkatan kesejahteraan dan pemerataan pembangunan desa melalui peningkatan pelayanan, memajukan perekonomian desa, mengatasi kesenjangan pembangunan antar desa, serta memperkuat masyarakat desa sebagai subjek pembangunan. Untuk mencapai tujuan tersebut dapat dilakukan dengan pembangunan sarana dan prasarana desa. Sedangkan ADD bersumber dari APBD 
yang peruntukannya adalah untuk operasional pemerintahan desa seperti penghasilan dan tunjangan perangkat desa, operasional perkantoran, biaya pembinaan lembaga kemasyarakatan desa, dan pembiayaan penyelenggaraan Musyawarah Rencana Pembangunan Desa (Musrenbangdes). Dengan kata lain, DD lebih diperuntukkan untuk kegiatan pembangunan fisik sedangkan ADD lebih pada pembiayaan kegiatan non fisik.

\section{Kesiapan SDM}

Kesiapan SDM dilihat dari
pemahaman perangkat desa dan masyarakat mengenai konsep atau materi tentang ADD yang kemudian disebarluaskan ke anggota masyarakat lainnya sehingga akan memantapkan langkah dalam mengelola keuangan desa terutama dalam pemilihan program pembangunan yang akan dilakukan yang tepat sesuai dengan yang dibutuhkan.

SDM dalam pengelolaan ADD adalah pemerintah desa yang bersangkutan, pemerintah desa ini adalah Kepala Desa dan BPD, yang dibantu oleh perangkatnya yaitu Sekretaris Desa, Kaur, Kasi, dan Kepala Dusun (Kadun). Selain itu, pada beberapa tahap juga melibatkan masyarakat, misalnya dalam penetapan rencana penggunaan dana yang dilakukan melalui Musrenbangdes. Masing-masing pihak yang terlibat dalam pengelolaan ADD ini harus memahami filosofi dari ADD itu sendiri, seperti memahami dari mana sumber ADD, diperuntukkan untuk apa, bagaimana cara mendapatkan dan menggunakannya, dana lain sebagainya. Kalau masing-masing pihak mempunyai satu pemahaman maka akan terhindar dari kesalahan dan penyimpangan yang mungkin terjadi.

Di kedua desa Tanjung Terdana tidak semua penyelenggara pemerintah desa berperan dalam pengelolaan ADD. Peran lebih banyak dijalankan oleh Kepala Desa, Sekretaris Desa, dan Bendahara (sekarang Kaur Keuangan). Karena ADD merupakan kebijakan baru maka perlu mempelajari konsep kebijakan tersebut sebelum melaksanakannya. Mulai dari memahami konsep ADD, cara mencairkannya, cara menggunakannya, dan cara mempertanggung jawabkannya. Dan semua aktivitas yang dilakukan untuk mendapatkan pemahaman tersebut dilakukan oleh ketiga unsur pemerintahan desa sebagaimana disebutkan di atas (Kepala Desa, Sekretaris Desa, dan Bendahara (Kaur Keuangan), yang kemudian menyebarkan informasiinformasinya kepada unsur pemerintah desa lainnya termasuk pada masyarakat. Penyebaran informasi ini dilakukan pada saat diadakan pertemuan-pertemuan menghimpun usulan-usulan kegiatan pembangunan, sosialisasi program, maupun pada saat penyusunan rencana pembangunan atau Musrenbang.

Dalam memahami konsep beserta aturan pelaksanaannya, pemerintah desa tersebut juga berkonsultasi dengan pihakpihak terkait yang berwenang, seperti pihak Kecamatan, Dinas Pendapatan, Pengelolaan Keuangan dan Aset (DPPKA) Kabupaten, Badan Pemberdayaan Masyarakat dan Pemerintahan Desa (BPMPD) Kabupaten. Konsultasi ini dilakukan secara langsung dengan datang ke kantor atau sekretariat dinas atau badan tersebut. Namun, dalam pelaksanaannya sedikit sekali dukungan dari pihak kecamatan dalam memberikan pemahaman berkaitan dengan pengelolaan ADD. Selain itu, usulan-usulan yang diajukan oleh desa tidak pernah diteruskan ke pihak yang menangani hehingga desa harus berkonsultasi langsung ke BPMPD dalam hal penyusunan perencanaan dan teknis pencairan, serta pertanggungjawaban, selain itu desa juga berhubungan langsung dengan DPPKA.

Selain itu, setiap desa juga mempunyai pendamping desa yang tugasnya adalah mengawal proses penyelenggaraan pemerintahan desa khususnya pengelolaan keuangan desa. Pendamping desa ini dapat dijadikan tempat konsultasi bagi pemerintah desa 
saat mengalami kesulitan atau kendala baik dalam hal administrasi maupun hal lainnya yang berhungan dengan penyelenggaraan pemerintahan desa. Namun, dikarenakan kompetensi dari pendamping desa ini tidak mencukupi sehingga dalam pelaksanaannya kinerja pendamping desa tersebut tidak maksimal. Dimulai dari tingkat pengetahuan dan pemahaman yang kurang sampai pada ketidakdisplinan pada jadwal pendampingan. Terlebih lagi, para pendamping ini umumnya berasal dari luar desa yang bersangkutan bahkan dari luar kabupaten sehingga semakin menyulitkan pemerintah desa untuk menemuinya.

Di desa Tanjung Terdana yang aktif dalam penyelenggaraan pengelolaan ADD adalah Kepala Desa, Sekretaris Desa, dan Bendahara Desa (sekarang Kaur Keuangan). Di desa ini, dalam struktur organisasi pemerintah desa-nya terdapat 3 (tiga) orang Kasi, dan 3 (tiga) orang Kadun serta 5 (lima) orang anggota BPD. Namun, perangkat desa tersebut sudah vakum selama 6 (enam) bulan. Hal ini disebabkan karena pola keseharian penduduk di desa ini didominasi kegiatan di sawah atau kebun sehingga waktu yang tersedia untuk melakukan aktivitas lain terbatas. Sedangkan dimalam hari kondisi badan sudaha lelah, sehingga sedikit sekali yang datang pada acara pemerintahan desa yang diselenggarakan pada malam hari. Untuk mengatasi hal tersebut, di tahun 2016 ini, kepala desa melakukan penggantian perangkat desa yang dilakukan melalui proses rekruitmen. Setiap penduduk yang memenuhi syarat diperbolehkan untuk mendaftarkan diri sebagai perangkat desa. Yang nantinya akan melalui proses seleksi baik secara administratif, tertulis, dan wawancara. Dengan demikian akan diperoleh perangkat-perangkat desa yang mempunyai motivasi dari dirinya untuk bekerja sesuai dengan tugasnya masingmasing.

Tetapi, meskipun perangkat desa vakum, masyarakat selalu dilibatkan dalam semua proses pembangunan desa, terutama masyarakat yang tergabung dalam anggota lembaga kemasyarakatan desa seperti Karang Taruna, PKK, Posyandu, dan Risma, dalam proses perumusan rencanarencana pembangunan desa yang disusun sesuai kebutuhan dan keinginan masyarakat, sepanjang program tersebut rasional dan tidak menyalahi aturan.

Perangkat desa di desa ini, kalau diihat dari tingkat pendidikannya merupakan lulusan Sekolah Menengah Atas, kecuali bendahara desa yang seorang sarjana. Tetapi di desa ini telah banyak warga yang lulusan sarjana, dan hal inilah yang dimanfaatkan oleh kepala desa dan sekretarisnya. Jadi, meskipun hanya lulusan SMA tetapi kepala desa dan sekretaris desa mempunyai kemampuan untuk memberdayakan warganya, karena mereka berkomitmen untuk memenfaatkan peluang pendanaan pembangunan desa guna meningkatkan kesejahteraan desa bukan hanya untuk kepentingan pribadi perangkat desa. Komitmen inilah yang membuat perangkat desa selalu transparan tentang apapun terutama dalam hal ketersediaan dan penggunaan dana yang pada akhirnya menimbulkan rasa kepercayaan masyarakat terhadap pemerintah desanya.

Perangkat desa juga antusias mengikuti Pendidikan dan Pelatihan (Diklat) yang diselenggarakan oleh BPK dengan peserta seluruh Kepala Desa dan Perangkatnya di Provinsi Bengkulu. Perangkat desa Tanjung Terdana mengikuti kegiatan tersebut hingga akhir, sementara perangkat desa dari lain banyak yang mengikuti hanya separuh jalan. Pemerintah desa Tanjung Terdana justru merasa masih perlu dilakukan lagi Diklat yang serupa.

Selain itu ketidak aktifan pendamping desa dalam memantau pelaksanaan pengelolaan ADD menyulitkan bagi aparat desa untuk berkonsultasi terkait dengan penyelenggaraan pemerintahan khususnya pengelolaan ADD. Di kecamatan Pondok Kubang terdapat 4 (empat) orang 
pendamping desa dimana setiap pendamping mendampingi 3 (tiga) desa. Dari keempat pendamping tersebut hanya satu yang dianggap oleh perangkat desa, termasuk perangkat desa Tanjung Terdana, yang memiliki pemahaman tentang ADD dan berperan aktif melakukan pendampingan ke desa-desa. Sehingga satu pendamping desa tersebut menjadi andalan semua perangkat desa dari 12 desa di kecamatan Pondok Kubang, koordinasi dan konsultasi lebih banyak ke pendamping desa yang dimaksud dari pada pendamping desa yang bertugas di desanya.

Desa Tajung Terdana, dapat memanfaatkan jaringan dari kalangan akademisi yang menjadikan desa tersebut sebagai objek penelitian maupun kegiatan pengabdian kepada masyarakat, untuk memperoleh pengetahuan secara akademik tentang penyelenggaraan pemerintahan desa khususnya pengelolaan ADD. Kegiatan akademisi yang sudah dilakukan adalah pengabdian kepada masyarakat dalam pembinaan penguatan organisasi karang taruna, Badan Permusyawaratan Desa (BPD), ibu-ibu PKK, dan perangkat desa yang dilakukan oleh akademisi dari FISIP Universitas Bengkulu. Bahkan dalam waktu dekat akan dibentuk perpustakaan desa, yaitu satu bentuk kegiatan pengabdian kepada masyarakat yang dilakukan oleh akademisi dari Universitas Bengkulu.

\section{Kesiapan Dalam Tata Laksana}

Kesiapan dalam tata laksana yang dilihat dari penyusunan program pembangunan yang berbasis kerakyatan, dan pembuatan laporan pertanggung jawaban. Tata laksana berkaitan dengan ketepatan dalam melakukan proses pengelolaan keuangan yang diawali dengan penyusunan program dan anggarannya. Kesiapan tata laksana berkaitan dengan jadwal pelaksanaan pengelolaan keuangan desa khususnya ADD yang harus sesuai dengan yang sudah ditentukan. Jadwal pelaksanaan yang dimaksud adalah jadwal penyusunan dokumen-dokumen pembangunan beserta anggarannya, meliputi Perdes tentang RPJMDes, RKPDes, dan APBDes. Dokumen tersebut harus dibuat tepat waktu supaya dananya juga cair tepat waktu.

Di desa Tanjung Terdana, berbagai
dokumen tersebut telah disusun.
Dokumen-dokumen tersebut dibuat berdasarkan aspirasi warga desa mengenai apa yang mereka butuhkan dan apa yang mereka inginkan. Namun dalam tata laksananya memang mengalami sedikit keterlambatan dikarenakan pedoman atau peraturan pelaksanaannya di tingkat daerah terbit setelah proses pencairan dana, sehingga memerlukan waktu untuk memahami isi dari peraturan tersebut sebelum dana yang sudah ada di kas desa dikelola atau digunakan.

Namun, meskipun demikian, desa Tanjung Terdana dipilih sebagai sampel untuk diaudit pengelolaan keuangannya oleh Badan Pemeriksa Keuangan (BPK). Dengan demikian banyak informasi dan pembelajaran yang diperoleh perangkat desa tentang pelaporan keuangan desa sehingga dapat menjadi masukan bagi pengelolaan keuangan di tahun berikutnya.

\section{Partisipasi Masyarakat dan Lembaga Kemasyarakatan Desa}

Partisipasi masyarakat dan lembaga kemasyarakatan desa yang dimaksudkan disini adalah partisipasi dalam bentuk menjadi anggota kelompok-kelompok masyarakat, melibatkan diri pada kegiatan diskusi kelompok, melibatkan diri pada kegiatan-kegiatan organisasi untuk menggerakkan partisipasi masyarakat yang lain, menggerakkan sumberdaya masyarakat, mengambil bagian dalam proses pengambilan keputusan, dan memanfaatkan hasil-hasil yang dicapai dari kegiatan masyarakatnya.

Di desa Tanjung Terdana, pada awalnya tingkat partisipasi masyarakatnya rendah, yang dikarenakan faktor kesibukan sehari dan adanya pengalaman yang 
kurang baik terhapat proses pembangunan terdahulu. Dimana saat itu mereka sering ikut terlibat dalam kegiatan-kegiatan perencanaan pembangunan seperti Musrenbang Daerah, tetapi karena tidak ada realisasinya sehingga lama-kelamaan rasa kepercayaan masyarakat berkurang dan mereka tidak mau lagi menghabiskan waktu untuk acara-acara yang berhubungan dengan pemerintahan dan pembangunan atau tidak lagi ikut berpartisipasi pada setiap pertemuanpertemuan yang diselenggarakan. Selain itu, adanya pandangan masyarakat yang menganggap bahwa setiap aktivitas pembangunan harus mendapatkan keuntungan secara materi, mengakibatkan setiap keterlibatan atau partisipasi harus diperhitungkan keuntungan bagi dirinya.

Tetapi Kepala Desa sebagai pimpinan terus berupaya memudarkan pemahaman tersebut dan bersama membangun komitmen untuk meningkatkan kesejahteraan desa dengan memanfaatkan kesempatan yang ada melalui DD dan ADD. Dari masyarakatlah penyelenggara pengelolaa ADD mengetahui apa kebutuhan dan yang diinginkan oleh masyarakat di desanya, dan sebisa mungkin kebutuhan dan keinginan tersebut direalisasikan dan dirumuskan dalam RPJMDes, RKPDes dan APBDes. Kepala Desa juga memotivasi lembaga-lembaga kemasyarakatan Desa untuk merancang program sesuai bidangnya untuk kemudian diberikan dukungan materil berupa dana dan atau barang. Sehingga secara bertahap tingkat partisipasi masyarakatnya meningkat.

Sejak digulirkannya dana ADD, kepala desa berusaha menumbuhkan kembali kepercayaan masyarakat tersebut supaya ikut berpartisipasi aktif kembali dalam semua proses pembangunan desa. Caranya adalah dengan terus menyampaiakan informasi-informasi penting, benar-benar merealisasikan usulan program pembangunan dari masyarakat sepanjang usulan tersebut tidak menyalahi aturan. Cara ini cukup berhasil meningkatkan kembali tingkat partsipasi masyarakat dalam pertemuan-pertemuan yang diselenggarakan oleh pemerintah desa maupun kegiatan pembangunan fisik yang dilakukan secara gotong royong. Selain itu, lembaga kemasyarakatan desa seperti Karang Taruna, PKK, Posyandu, Risma, Kelompok Tani, dan lembaga kemasyarakatan desa lainnya diberdayakan dengan diberikan kesempatan untuk mengajukan program kegiatan masingmasing organisasi untuk dimasukkan ke dalam RPKDes tahun yang bersangkutan. Pemberian kesempatan ini didahului dengan pembuatan komitmen antara perangkat desa dan anggota Lembaga Kemasyarakatan Desa, bahwa program yang diusulkan benar-benar akan dilaksanakan dan memberikan manfaat. Dengan cara ini, perangkat desa yang baru, anggota lembaga kemasyarakatan desa, dan masyarakat pada umumnya menjadi lebih bersemangat untuk membangun desa bersama-sama.

\section{PENUTUP \\ Kesimpulan}

Di desa Tanjung Terdana meskipun pada awalnya belum memahami tentang konsep pengelolaan keuangan desa khususnya ADD yang nominalnya jauh lebih besar dari sebelumnya tetapi mereka mempunyai komitmen dan kemajuan untuk membangun desa dengan memanfaatkan ADD. Jadi meskipun peraturan pelaksanaan di tingkat daerah lambat ditetapkan, sehingga tata laksananya tidak dapat sesuai dengan jadwal yang telah ditetapkan, tetapi Kepala Desa dan perangkatnya berkonsultasi ke beberapa pihak yang berwenang. Adanya kemauan untuk belajar, memperbaiki kesalahan, dan usaha, maka perlahan kesiapan desa dalam pengelolaan ADD semakin meningkat. Ditambah dengan partisipasi masyarakat yang terus meningkat karena Kepala Desa dan perangkatnya memberikan bukti degan merealisasikan rencana atau program 
pembangunan yang diusulkan oleh masyarakat.

\section{Saran}

Sementara ini, yang dapat peneliti sarankan adalah secara umum perlu peningkatan diklat tentang pengelolaan keuangan desa, dan optimalisasi peran pihak-pihak yang berwenang terkait pembinaan terhadap desa dalam pengelolaan ADD seperti pihak kecamatan dan pendamping desa yang selama ini belum berperan secara optimal supaya desa-desa lebih siap dalam penyelenggaraan pengelolaan ADD khususnya. Desa Tanjung Terdana juga dapat lebih memanfaatkan jaringan yang sudah terbangun dengan pihak luar desa baik kalangan akademisi, maupun pihak atau instansi lain yang telah menaruh perhatian terhadap desa Tanjung Terdana.

\section{DAFTAR PUSTAKA}

Buku :

Creswell, John W. 2010. Research Desighn, Pendekatan Kualitatif, Kuantitatif, dan Mixed. Yogyakarta: Pustaka Pelajar.

Mardikanto, Totok, dan Poerwoko Soebiato. 2015. Pemberdayaan Masyarakat dalam Perspektif Kebijakan Publik. Bandung: Penerbit ALFABETA.

Soemantri, Bambang Tri Santono. 2011. Pedoman penyelenggaraan Pemerintah Desa. Bandung: CV. Fokus Media.

Soetomo. 2011. Pemberdayaan Masyarakat, Mungkinkah Muncul Antitesisnya?. Yogyakarta: Pustaka Pelajar.

Sudarsa, Agun Gunandjar. 2013. Membangun Indonesia Sejahtera Langkah Nyata Menuju Visi Indonesia 2020. Jakarta: Penerbit RMBOOKS.

Sugiyono. 2009. Metode Penelitian Kualitatif, Kuantitatif, dan $R \& D$. Bandung: Penerbit Alfabeta.
Sutopo, H. B.. 2002. Metodologi Penelitian Kualitatif, Dasar Teori dan Terapannya dalam Penelitian. Surakarta : Sebelas Maret University Press.

Winarno, Budi. 2013. Etika Pembangunan. Yogyakarta: CAPS (Center for Academic Publishing Service).

Hasil Penelitian Terdahulu:

Aminudin, Ahcmad, dkk. 2014. Modal Sosial dalam Pembangunan Desa Tanjung Terdana Kabupaten Bengkulu Tengah. Hasil Penelitian yang Didanai Oleh PNBP FISIP Universitas Bengkulu Tahun 2014.

Peraturan Perundangan:

Undang-Undang Nomor 6 Tahun 2014 Tentang Desa

Undang-Undang Nomor 3 Tahun 2015 Tentang Perubahan Atas UndangUndang Nomor 27 Tahun 2014 Tentang Anggaran Pendapatan dan Belanja Negara Tahun Anggaran 2015.

Peraturan Pemerintah Nomor 47 Tahun 2015 tentang Perubahan Peraturan Pemerintah Nomor 43 Tahun 2014 tentang Peraturan Pelaksanaan Undang-Undang Nomor 6 Tahun 2014 tentang Desa.

Peraturan Pemerintah Nomor 22 Tahun 2015 Tentang Perubahan Atas Peraturan Pemerintah Nomor 60 Tahun 2014 Tentang Dana Desa yang Bersumber Dari Anggaran Pendapatan dan Belanja Negara

Permendagri Nomor 113 tahun 2014 Tentang Pengelolaan Keuangan Desa

Permendagri Nomor 114 tahun 2014 Tentang Pembangunan Desa

Internet :

http://www.marketrends.asia/2013/02/focu s-group-discussion-research.html 
Jurnal Professional FIS UNIVED Vol. 3 No. 3 Desember 2016

Komisi Pemberantasan Korupsi. 2015. Laporan Hasil Kajian Pengelolaan Keuangan Desa: Alokasi Dana Desa dan Dana Desa. Suyatno. 2015. Menyoal Kesiapan Pemerintah Desa. www.kpk.go.id wWw.metrotvnews.com 